\title{
WILLINGNESS TO PAY FOR CONSERVATION OF NATURAL RESOURCES IN SANTUBONG NATIONAL PARK
}

\author{
Thalany Kamri ${ }^{1}$, Jati Kasuma Ali ${ }^{1}$, Nurul Fahana Aini Harun ${ }^{1}$ \\ ${ }^{1}$ Faculty of Business Management, University Teknologi MARA, 94300 Kota Samarahan, \\ Sarawak, Malaysia. \\ * Corresponding author; Email: jati@sarawak.uitm.edu.my
}

\begin{abstract}
Gunung Santubong National Park (GSNP) is one of the attractions in Sarawak that needs attention for conservation. A contingent valuation method of survey was conducted to estimate the conservation value of GSNP and to elicit the willingness to pay among respondents. Through the random survey, the estimated mean of willingness to pay for conservation fee per respondent was RM8.41. With the number of visitors of 24066 in year 2016, it is estimated that there is an additional RM 202,395.06 that could be used for the improvement in environmental conservation. This study shows that contingent valuation method is a useful tool to guide decision makers in policy purposes of natural resources management of protected area in developing countries.
\end{abstract}

Keywords: Contingent valuation, national park, conservation, willingness to pay, Sarawak.

\section{Introduction}

National park like other environmental resources and public goods used by humans can benefit in many different ways. Those environmental resources have many functions relating to the ecological functions. They also offer recreational resources to everyone who visits this park. National parks which are offered as ecotourism sites can enhance national income, and have economic impacts to society around the area of national park. Then, it can make up the national economic growth (Cessford \& Burns, 2008). National Park also announced as one of the categories under Total Protected Areas (TPA) which can be visited (Dumitras, Arion, \& Merce, 2011).

However, many national parks are not equipped to handle the cost of management and conservation system which lacks of management capability, sufficient staff, insufficient finance capability and infrastructure (Eagles, 2002). Consequently, Eagles (2002) suggested that "values and valuation influence how parks are being managed". The economic theory suggests that to measure the value of environmental resources provided in national park is to look at what public visitors are willing to pay for them. Therefore, there is a need to understand visitors needs and wants (Eagles, 2002), and incorporate visitors' preferences for nature appreaciation, infrastructure, use restrictions and other attributes of national parks (Hearne \& Salinas, 2002) to enable for better conservation (United Nations Environment Programme, 2003).

\section{Description Areas}

One of the most popular national parks in Sarawak is Gunung Santubong National Park
(GSNP). The parks and nature reserves showcases the park's natural heritage and act as one of the key attraction for Sarawak's expanding tourism industry. It is worth for the visitor to reach on the top of GNSP with wonderful feeling of which they could see the whole of Kuching City including river surrounding the mountain. GNSP is only 810 meters high and it is a single rise mountain with a short range out of a relatively flat terrain by the sea. Being the most strategic national park which is located at Kuching, Sarawak attracts mostly 24,066 numbers of visitors in year 2016 (Sarawak Forestry Department, 2016).

GSNP which is among the 30 national parks in Sarawak has only entrance fee charges of RM 20 for foreign visitors and RM 10 for locals. These collections are put into Forest Trust Fund managed by Sarawak Forest Department (SFD) which is used for the operating, managing and building of infrastructure in national parks. However, most of the national parks cannot generate enough funds to sustain on its own.

Entrance fee would not give sufficient contribution to manage the cost of conservation and management for this area, and this problem might affect the sustainability of nature reserve for the next generation. In addition nature reserve is categorized as non marketable goods which cannot be value like other economic goods. It's really difficult to put some value on these non market environmental goods since there is no available pricing system introduced for these goods. In the meantime, some of the people, as well as visitors are less of awareness of national park conservation when they did not have to pay any entrance fees.

Therefore, it is necessary to convince the people, public and other stakeholders of the usefulness of 
national parks conservation by putting some value of its. Eagles (2002) are suggested that "values and valuation influence how parks are being managed". Thus, this study is to attempts to determine willingness to pay to enter the GSNP and factors affecting them to pay for. The benefit of the collection will be used as a fund to help manage conserves the biodiversity of the park. Thus, the objective of this study is to determine willingness to pay for conservation of GSNP.

\section{Conservation}

Conservation is the protection and maintenance of nature while allowing for its ecologically sustainable use. Ecologically sustainable use is in relation to wildlife or in relation to protect the areas. It might include the process of maintaining the life support system of nature and ensuring that the benefits of the use to present generations does not diminish the potential to meet the needs and aspiration of future generations (Queensland, 2015).

Conservation is very important and is the main idea of the study. For many years, countless research has been done to better understand and aid in the conservation activities. Benefits from conservation activities and implementations means that long term sustainability of an ecosystem, hence benefits not only biodiversity itself but also the quality of life of future generations. The effects of conservation management activities on ecosystem services indicate that restoring vegetation can improve water quality and water storage functions, can reverse soil degradation on a local scale, and can restore plant-insect interactions ( $\mathrm{McAl}-$ pine, 2007). Other than that, maintaining biodiversity preserves genetic libraries and future options for discoveries of valuable biological compounds (McAlpine, 2007).

In order to be successful, conservation must have strategies. Where? In terms of places to conserved. What? Species, flora, fauna, and ecosystem will conserved and others. Strategies make sure conservation activities are successful. The success of conservation strategies through protected areas may lie in the ability of managers to reconcile biodiversity conservation goals with social and economic issues and to promote greater compliance of local communities with PA conservation strategies (Gustava, 2012). Most conservation management agencies for protected natural areas (e.g. national parks) have a common responsibility for the protection of natural, historic and cultural heritage values, while simultaneously allowing the use of these areas for recreation and tourism (Cessford \& Burns, 2008).
The realization of conservation goals requires strategies for managing whole landscapes including areas allocated to both production and protection. Reserves alone are not adequate for nature conservation but they are the cornerstone on which regional strategies are built. Reserves have two main roles. They should sample or represent the biodiversity of each region and they should separate this biodiversity from processes that threaten its persistence. Existing reserve systems throughout the world contain a biased sample of biodiversity, usually that of remote places and other areas that are unsuitable for commercial activities. A more systematic approach to locating and designing reserves has been evolving and this approach will need to be implemented if a large proportion of today's biodiversity is to exist in a future of increasing numbers of people and their demands on natural resources (Margules \& Pressey, 2000).

\section{Willingness to Pay (WTP)}

Willingness to pay refers to the intention of people whether they are able and want to without hesitation and influenced by factors which includes level of satisfaction. This is based on the welfare theory by Dupuit. Welfare economics is dealing on how to derive the measures of a change in individual satisfaction due to a change in price and quantity or quality of goods and services provided (Markandya, Harou, Bellu, \& Cistulli, 2002). Welfare theory is used to determine the impacts of economic changes onto consumer utility (McKenzie, 1983). The idea of consumer welfare through consumer surplus was introduced by the work of Dupuit in the analysis of cost and benefits generated by a project (McKenzie, 1983). According to Dupuit, utility of a good derived from the price that consumer pay plus the addition of their WTP above the price charged. This difference between WTP and the actual price charged is known as consumer surplus.

\section{Research Method}

The study was derived from a random survey of 360 respondents covered from GSNP, Kuching and Kota Samarahan area. The face to face interviews by using questionnaire consisted of four sections. Section A, B, C and D. In Section A, respondents were asked about their past experience at the park, whether they have or have not visited the park before and also if they did ever visited before, how many times have they visited the park. Section B covered on respondents' reasons to visit. Different reasons were suggested where respondents have to either agree or 
disagree with the statements provided. The most crucial feedback required was in Section C. this was on their willingness to pay and the exact amount of conservation fee they were willing to pay. For this, they were required to answer either "Yes" or "No". Next question was to discover the respondents' maximum willingness to pay for conservation fee. The final section $\mathrm{D}$, non-visitors were asked about their demographic, personal backgrounds.

Forms of data analysis that will be performed are descriptive analysis, factor analysis and multiple regression analysis and Contingent Valuation Method (CVM). Descriptive analysis is used to provide information on socioeconomics variables such as ages, education level, level of income, and gender of the respondents. The purpose of Factor analysis is to identify the factors that provide highest loading variables on each of the factor can be used to identify the nature of the underlying latent variable represent by each factor.

In order to gain the first research objective, regression analysis is used because it shows the relationship between the dependant and independent variables. This method will allow the effect of independent variables, onto dependent variables, whether it has a positive or negative relationship, and revealing which factors (independent variables) affects WTP (dependent variable) the most.

Furthermore, CVM is used to discover how much the respondent's willing to pay for conservation of the park similar with second objective of this research. This approach is called an open ended question. The respondents will be asked generally how much they are willing to pay for conservation fee. All of these respondents showed their WTP for conservation.

\section{Result and Discussion}

Descriptive analysis was used to analyse respondents of GSNP demographic and characteristic. All the information would be defined in percentage (\%) and frequency. Table 1 displays the summary of respondent's demographic characteristics. By gender, half from respondent $(50.6 \%)$ were male. More than half $(88.6 \%)$ were single. Most of the respondents (96.5\%) were between 20 to 29 years old, the rest of the age group was 13-19 (6.4\%), 30-39 (14.7\%) and $40-49(5.6 \%)$. Majority (85\%) of respondents were domestic, while the rest $(24.6 \%)$ are international. In terms of educational background, $70.6 \%$ had attained degrees. $15.3 \%$ of the respondents had diploma. Most respondents $(55.6 \%)$ were students from either UiTM or Unimas, and the rest $(32.5 \%)$ were government servants. In terms of income, majority of visitors (46.9\%) earned an income of less than RM 1000 and (44.4\%) don't have any income.

Table 1

Respondents Profiles

\begin{tabular}{lcc}
\hline Characteristics & $\begin{array}{c}\text { Percentage } \\
(\boldsymbol{\%})\end{array}$ & $\boldsymbol{N}$ \\
\hline Gender: & 50.6 & 182 \\
Male & 49.4 & 178 \\
Female & & \\
Marital status: & 88.6 & 319 \\
Single & 11.4 & 41 \\
Married & & \\
Nationality: & 75.4 & 341 \\
Malaysian & 24.6 & 19 \\
International & & \\
Age: & 6.4 & 23 \\
13-19 & 71.7 & 258 \\
20-29 & 14.7 & 53 \\
30-39 & 5.6 & 20 \\
40-49 & 1.7 & 6 \\
> 50 & & \\
Education level: & 12.8 & 46 \\
Master Degree/PhD & 70.6 & 254 \\
Bachelor Degree & 15.3 & 55 \\
Diploma & 1.4 & 5 \\
Secondary/Primary School & & \\
Occupation: & & \\
Self employed & 11.9 & 43 \\
Government servant & 32.5 & 117 \\
Student & 55.6 & 200 \\
Monthly Income: & & \\
<RM1000 & & \\
RM1000-RM1999 & 46.9 & 169 \\
RM2000-RM2999 & 7.5 & 27 \\
> RM3000 & 0.8 & 3 \\
Don't have any income & 0.3 & 1 \\
Have been visit SNP before: & 44.4 & 169 \\
Yes & & \\
No & 61.9 & 223 \\
If Yes, how many times: & 38.1 & 137 \\
1-2 & & \\
>2 & 83.6 & 187 \\
\hline & 16.4 & 36 \\
\hline & & \\
& & \\
& &
\end{tabular}

\section{Factor Analysis}

Result of Table 2 shows the highest loading variables on each of the factor can be used to identify the nature of the underlying latent variable represent by each factor. By using Cronbach's alpha reliability test, the main loading on factors 1 are the variables $(b$, $\mathrm{c}, \mathrm{d}, \mathrm{a}, \mathrm{e}$, and f) on section $\mathrm{B}$ in the questionnaire. This all variable can be category as improving self-skills. The variables on the factors $2(\mathrm{n}, \mathrm{m}, \mathrm{o}, \mathrm{p})$ are represent to build a good relationship among people. Those variables related to nature and harmony mainly affected factors 3 , while for the factors $4(\mathrm{r}, \mathrm{q}, \mathrm{s})$ can be label as to reduce stress. However, there are two of 
the variables are eliminated from the item reduce stress which is item $g$ and $t$, which are has a weak relationship between the factors. Hence, factor analysis was carried out 18 items out of 20 items. Then, this data were than calculated and entered as four preferences variables together with socio demographics factors in estimating WTP.

Table 2

Rotated Factor Matrix

\begin{tabular}{|c|c|c|c|c|c|}
\hline \multirow{2}{*}{\multicolumn{2}{|c|}{$\begin{array}{c}\text { Characteristics/Item } \\
\text { numbers }\end{array}$}} & \multicolumn{4}{|c|}{ Factors } \\
\hline & & 1 & 2 & 3 & 4 \\
\hline$\overline{\text { a) }}$ & Challenge and skills: & & & & \\
\hline 1) & $\begin{array}{l}\text { To be in charge of a } \\
\text { situation }\end{array}$ & 0.935 & & & \\
\hline 2) & To feel independent & 0.923 & & & \\
\hline 3) & To develop skills & 0.886 & & & \\
\hline 4) & $\begin{array}{l}\text { To challenge skills and } \\
\text { abilities }\end{array}$ & 0.851 & & & \\
\hline 5) & $\begin{array}{l}\text { To feel free from } \\
\text { society's restriction }\end{array}$ & 0.785 & & & \\
\hline 6) & To challenge nature & 0.742 & & & \\
\hline b) & Friends and Family: & & & & \\
\hline 1) & $\begin{array}{l}\text { To be with people with } \\
\text { similar interest }\end{array}$ & & 0.876 & & \\
\hline 2) & $\begin{array}{l}\text { To do things with other } \\
\text { people }\end{array}$ & & 0.812 & & \\
\hline 3) & $\begin{array}{l}\text { To be with my friends } \\
\text { and family }\end{array}$ & & 0.810 & & \\
\hline 4) & $\begin{array}{l}\text { To strength relationship } \\
\text { with friends and family }\end{array}$ & & 0.805 & & \\
\hline
\end{tabular}

\section{c) Nature and} Harmony:

1) To obtain feeling of $\quad 0.887$ harmony

2) To observe the beauty 0.848 of nature

3) To find quit places

0.836

4) To enjoys sights, 0.628 sounds and smells of nature

5) To feel close to nature

0.509

d) Reduce Stress:

1) To release stress 0.886

2) To be alone $\quad 0.873$

3) To be away from other $\quad 0.845$ people

0.735

4) To escape from pressure of work

5) To get away from everyday routine

*Extraction Method: Principal Axis Factoring.

Rotation Method: Varimax with Kaiser Normalization.

Rotation converged in 6 iterations.

\section{Regression Analysis}

Regression analysis was used to predict the relationship between Willingness to Pay for Conser- vation and the independent variables (Demographics and four factors identified in factor analysis). The result obtained is presented in Table 3. As can be seen from the table, the value of $R$ Square is 0.598 , which means that the regression model explains $59.5 \%$, more than half, of the behavior of the dependent variable is explained and affected by the behavior of independent variables. However, the remaining $40.2 \%$ is affected by factors which are not included in this study.

Referring to this study's theoretical framework, there is strong evidence of WTP for conservation affected by education level positively, gender and age negatively. This result is significant at 1 percent and 10 percent level. This means that the increasing number of years studying (education level) would increase their willingness to pay (WTP). More specifically, a one percent increase in years of education it would increase WTP by an average of 0.196 percent. This result implies that, as such it will increase his or her knowledge and may ultimately have an impact on the thinking of a rational person. This normally will shape his/her perception and attitude in a more matured manner. Since what he learns is embedded in him as a person, the effect of education on his/her behaviour is usually quite strong, especially, if it is consistent with his perception such as the WTP.

Table 3

\section{OLS Regression Estimates}

\begin{tabular}{lccc}
\hline Variable & Coefficient & Std error & $\boldsymbol{t}$-statistic \\
\hline Constant & -0.670 & 0.910 & \\
Income & 0.097 & 0.079 & 1.231 \\
Age & $-0.115^{*}$ & 0.067 & -1.712 \\
Nationality & 0.037 & 0.038 & 0.953 \\
Gender & $-0.049 * * *$ & 0.020 & -2.471 \\
Marital status & -0.120 & 0.133 & -0.897 \\
Education & $0.196 * * *$ & 0.033 & 6.026 \\
Challenge \& & 0.003 & 0.003 & 0.957 \\
Skills & & & \\
Friends \& Family & $0.022 * * *$ & 0.005 & -4.248 \\
Nature \& & 0.007 & 0.005 & 1.462 \\
Harmony & & & \\
Reduce Stress & $0.017 * *$ & 0.008 & 2.054 \\
Previous visits & $0.181 * * *$ & 0.029 & 6.161 \\
Have you ever & -0.015 & 0.027 & -0.552 \\
visit SNP & & & \\
\hline$F$ stats & 0.598 & & \\
d.f. & 0.570 & & \\
* denotes statistically siginificant at 90\% confidence level \\
$* *$ denotes statistically siginificant at 95\% confidence level \\
$* * *$ denotes statistically siginificant at $99 \%$ confidence level
\end{tabular}

Consequently, a negative relationship was found between WTP and age. On average, one percent increase in the number of ages would decrease their 
willingness to pay for conservation by 0.119 percent. Interestingly, negative sign of gender coefficient represent male respondent have tendency to pay more the WTP for conservation rather than female respondents with the difference in amount by 0.049 percent. However, there is no significant differences were found between respondent income and nationality towards WTP.

From four attitude variables resulting from factor analysis, two of them were significant, the positive sign of factor 2 means that WTP would increase if respondent's preference to visit the park was to enjoy with family and friends. Specifically, one percent increase in the factor of build relationship will result in an increase of WTP by 0.018 percent. Moreover, factor 4 also show the positive significant relationship between WTP and reduce stress at five percent level. This positive sign implies that when respondent preference visits to the SNP to reduce their stress, hence the volume of WTP for conservation will be increase. From the model also, factor 1 (challenge or skills) and factor 3 (nature and harmony) does not affect WTP at all. This means, respondent WTP is actually not influence by the challenging activity at SNP. Moreover, past experience, as assumed in the study's theoretical framework, would affect non-visitors' WTP. If non-visitors have in fact, had experience at the park, then their WTP would increase. Precisely, if one percent increases of "have you ever visited GSNP before?" WTP will increase at an average of 0.177 percent.

Other recommendations on what other variables that can affect WTP are, attractiveness of the park for family and friends gathering spot area, for example resting place, gazebos, mosque and barbeque area. Since most of respondents satisfaction go to these parks to enjoy with their family and friends, this could be a variable which can in fact affect WTP. Other than that, another variable affect WTP is to reduce stress. This refers to how the management maintains the nature of SNP becomes greener and harmony in order to catch the attention of visitors, since most of respondents wants to visit SNP to reduce stress.

\section{Respondent's Willingness to Pay for Conservation}

Table 4 is the results of respondent's opinion on how much are they willing to pay exactly for the conservation fee at GSNP. Only $0.8 \%$ of them agreed on the fee between RM 1-RM 2. Majority of them agreed on the range of RM 5-RM 6 which accounted at $35.3 \%$. The range between RM 3-RM 4 and RM 7-RM 8 are $12.2 \%$ and $10.8 \%$ respectively. Thus, respondents agree on the range of RM 5 and RM 6 to be most suitable and affordable for conservation fee at the park.

\section{Table 4}

\section{Public's WTP}

\begin{tabular}{lcc}
\hline RM & $\boldsymbol{N}$ & Percentage \\
\hline $1-2$ & 3 & 0.8 \\
$3-4$ & 44 & 12.2 \\
$5-6$ & 127 & 35.3 \\
$7-8$ & 39 & 10.8 \\
$9-10$ & 53 & 14.7 \\
$11-12$ & 19 & 5.3 \\
$13-14$ & 12 & 3.33 \\
$15-16$ & 57 & 15.8 \\
$17-18$ & 3 & 0.83 \\
$19-20$ & 2 & 0.6 \\
$>20$ & 1 & 0.3 \\
\hline
\end{tabular}

Table 5

Public's WTP (Mean)

\begin{tabular}{cc}
\hline Respondents $(\boldsymbol{n})$ & Conservation fee (RM) \\
\hline 360 & 8.41 \\
\hline
\end{tabular}

Table 6

Estimated Revenue from Conservation Fee

\begin{tabular}{ll}
\hline Year & Estimated additional revenue $(\mathbf{R M})$ \\
\hline 2016 & $202,395,06$ \\
\hline
\end{tabular}

\section{Conclusion}

The study concludes that most of the respondents are willing to pay for conservation fee at GSNP. The park is a majestic place worthy to be conserve and protect so that future generation can continue to enjoy and appreciate its beauty.

Based from the study, the results obtained in regression can be used as an input in the planning process and managerial policy implications. The results of the study showed that the willingness to pay for conservation fee are in fact influenced by respondents education level, the family and friends factor and if respondents have ever visited the park before. GSNP management and stakeholder can use the information and implement a suitable pricing strategy of the conservation fee for visitors. Since respondents with a higher education level tends to be more willing to pay for conservation fee, the park management can target their park towards people with higher education such as visiting local universities and giving talks and awareness about the park.

This study revealed that respondents with a high education level are willing to pay more for conservation fee. Sarawak Forestry Corporation (SFC) should implement education program, aimed to in- 
crease the level of awareness among non-visitors. Respondents, who are well informed about the park, have a more positive perception and decision towards conservation fee. Management plans supported by this research will be more credible and the management team of the park can use it to justify any changes such as an increase in fee to the authorities and the public.

The management of the park should ensure pristine conditions of their public infrastructure if not improve by offering more. For example, ensuring hiking path is safe and is up to standard and making sure facilities such as toilets are clean. Notices should be erected at every entrance to be educating awareness and civic virtue of the recreationists of the significance of every living thing in the area; flora and fauna and their co-operation and togetherness to protect such areas is needed.

\section{References}

Andrade, G. S. M. \& Rhodes, J. R. (2012). Protected areas and local communities: An inevitable partnership toward successful conservation strategies? Ecology and Society, 17(4), 14.

Cessford, G. \& Burns, R. (2008). Monitoring visitor numbers in New Zealand national parks and protected areas. New Zealand: Science \& Technical Publishing.

Dumitras, D. E., Arion, F. H., \& Merce, E. (2011). A brief economic assessment on the valuation of national and natural parks: The case of Romania.
Notulea Botanicae Horti Agrobotanici ClujNapoca, 39(1), 134-138.

Eagles, P. F. (2002). Trends in park tourism: Economics, finance and management. Journal of Sustainable Tourism, 10(2), 132-153.

Hearne, R. R. \& Salinas, Z. M. (2002). The use of choice experiments in the analysis of tourist preferences for ecotourism development in Costa Rica. Environmental Management, 65(2), 153163.

Margules, C. R. \& Pressey, R. L. (2000). Review article systematic conservation planning. Nature International Weekly Journal of Science, 405, 243-253.

Markandya, A., Harou, P., Bellu L. G., \& Cistulli, V. (2002). Environmental economics for sustainable growth. Cheltenham: Edward Elgar.

McAlpine, K. G. \& Wotton, D. M. (2007). Conservation and the delivery of ecosystem services. New Zealand: Publishing Team Department of Conservation.

McKenzie, G. W. (1983). Measuring economic welfare: New methods. Cambridge: Cambridge University Press.

Queensland. (2015). Nature conservation act 1992.

Sarawak Forest Department. (2016). Visitor statistics to national park. Retrieved May 25, 2016, from Sarawak Forest Department: www.Forestry. Sarawak.Gov.My/Modules/Web/Page.Php?Id= 1067 \&MenuId=0subId=291.

United Nations Environment Programme. (2013). UNEP annual report 2013. 